\title{
Isolation and Identification of Potential DNA Helicase from Local Isolate of Candida Albicans
}

\author{
Haw Boon Ping, Asma Ismail, Eugene Ong Boon Beng, and Sasidharan Sreenivasan
}

\begin{abstract}
Candida albicans is a most common fungal pathogen that causes oral and genital infections in human. This pathogen can causes candidiasis, especially in person with immunocompromised. Local isolated $C$. albicans has been successfully identified based on its phenotype and genotype characteristics. ITS amplification was performed using ITS1 and ITS4 primers. $C$. albicans is also exhibits as mesophilic fungus. Due to this reason, we believed that this microorganism has the potential to produce a mesophilic form of DNA helicase. In this study, a potential DNA repair helicase gene has been successfully amplified and identified from the local isolated $C$. albicans. DNA helicase was known as a motor protein for unwinding of duplex DNA into single stranded DNA using energy derived from ATP hydrolysis. However, a further study is needed to verify and validate the DNA helicase unwinding activity in future.
\end{abstract}

Index Terms - Candida albicans, DNA helicase, genotype, mesophilic fungus.

\section{INTRODUCTION}

In this modern day, polymerase chain reaction (PCR) is widely used in medical and biological applications [1]. Polymerase chain reaction was discovered by Kary Mullis in 1983. This PCR method has been reported to be a promising method in the diagnosis of pathogens as it is highly sensitive and specific [2], [3]. Nevertheless, this method requires expensive instrumentation and well-trained personnel to operate. In order to get rid of these problems, a new technology called helicase-dependent amplification (HDA) has been developed. HDA is an in vitro DNA amplification method that works at isothermal condition [4]. Several articles have been published recently on using HDA as a rapid method for detection of various pathogenic microorganisms [5], [6]. Like PCR, this method relies on the use of a DNA helicase to unwind the double-stranded DNA and RNA-DNA hybrid into single-stranded templates for primer hybridization and DNA polymerase to synthesize DNA, but without the need for thermal cycling [7]. HDA is very versatile, sensitive and specific as well as low cost for instrumentation [8]. Hence, this characteristic makes the HDA technology highly decent for rapid pathogen detection applications, especially at point-of-care diagnostics.

The first DNA helicase was discovered and characterized

Manuscript received December 14, 2012; revised May 7, 2013. This work was supported in part by the Universiti Sains Malaysia (USM) under Grant 1001/PSKBP/86300110.

Haw Boon Ping, Eugene Ong Boon Beng and Asma Ismail are with the Institute for Research in Molecular Medicine (INFORMM), USM, 11800 USM, Penang, Malaysia (e-mail: hbping87@gmail.com, srisasidharan@yahoo.com, asmainformm @ yahoo.com, eugene@usm.my). more than 30 years [9]. Since then, several fascinating enzymes have been identified and characterized, and most of these enzymes have been proposed to possess helicase activity based on their biological functions [10]. DNA helicases are a class of enzymes essential to all living organism. These enzymes play important role in a variety of cellular processes such as DNA replication, DNA repair, DNA recombination, transcription and translation [11], [12]. The first eukaryotic DNA helicase was reported from lily in 1978. All the DNA helicases share some common properties, including nucleic acid binding, NTP binding and hydrolysis, separating of duplex DNA in 3' to 5' or 5' to 3' direction. The first eukaryotic DNA helicase was identified from lily plant in 1978 [13], [14].

Candida albicans is a eukaryote and a dimorphic fungus that grows both as yeast (blastospore) and filamentous (hyphae) cells [15]-[17]. It is a normal gut flora in the human mouth and gastrointestinal tract. C. albicans is a mesophilic microorganism that grows in in moderate temperatures, ranging from $25^{\circ} \mathrm{C}$ to $40^{\circ} \mathrm{C}$ [18]. However, it is an opportunistic fungal pathogen that causes oral and genital infections in humans [19], [20]. Hence, the biological characteristics of $C$. albicans make it an interesting model to isolate and identify the potential DNA helicase in present study.

\section{MATERIALS AND METHODS}

\section{A. Isolation and Identification of Microorganism}

Clinical samples of Candida species were collected from Hospital Universiti Sains Malaysia, Kelatan, Malaysia. The clinical strains were isolated from local patients with Candida species infection. The isolated strains of Candida species were cultured onto Sabouraud's dextrose agar (SDA) and incubated at $37^{\circ} \mathrm{C}$ for 18 hours. Then, the pure culture was cultured onto chromogenic culture medium, ChromID Candida medium at $37^{\circ} \mathrm{C}$ for 24 hours.

\section{B. Microscopy Examination and Morphological Studies}

Morphological characteristics of isolated microorganism were investigated using scanning electron microscope. An 18 hours old microbial culture was used to identify its ultrastructure. Germ tube test was performed to identify the germ tubes formation of isolated microorganism using phase contrast microscopy as mentioned in Williams, D. and Lewis, M. (2000).

\section{Genotype Identification}

Colony PCR was performed to investigate the genetic typing of isolated Candida species. The optimized PCR 
reaction mixture contained of $1 \times$ Taq buffer $(75 \mathrm{mM}$ Tris- $\mathrm{HCl}$, $20 \mathrm{mM} \mathrm{KCl}, 5 \mathrm{mM}\left(\mathrm{NH}_{4}\right)_{2} \mathrm{SO}_{4}, 0.05 \%$ (v/v) Nonidet P40, $\mathrm{pH}$ 8.8), $2.5 \mathrm{mM} \mathrm{MgCl} \mathrm{Mg}_{2}, 0.2 \mathrm{mM}$ dNTPs, $1 \mu \mathrm{M}$ of each ITS primer, 2.5U Taq DNA polymerase (recombinant). The volume was made up to $50 \mu \mathrm{l}$ with sterile deionized water. A single colony of isolated microorganism was added as DNA template. The list of primers for colony PCR was shown in Table I. The mixture was pre-heated and mixed at $94^{\circ} \mathrm{C}$ for 3 min. Colony PCR was performed under the following conditions, one cycle of $94^{\circ} \mathrm{C}$ for $7 \mathrm{~min}$ and 35 cycles of $94^{\circ} \mathrm{C}$ for $45 \mathrm{~s}, 56^{\circ} \mathrm{C}$ for $1 \mathrm{~min}, 72^{\circ} \mathrm{C}$ for $1 \mathrm{~min}$. Thermal cycles were terminated by polymerization at $72^{\circ} \mathrm{C}$ for $5 \mathrm{~min}$, and a final incubation at $4^{\circ} \mathrm{C}$.

\section{Sensitivity of Colony PCR}

The isolated microorganism was cultured overnight at $37^{\circ} \mathrm{C}$ until $\mathrm{OD}_{600}$ reached 1.0, which is corresponds to $10^{7}$ cells $/ \mathrm{ml}$. Tenfold serial dilutions of overnight culture were prepared. Each dilution was centrifuged, and the cell pellet was washed once with sterile deionized water and then used as DNA template for colony PCR.

\section{E. Detection of Colony PCR Products}

PCR-amplified DNA fragments were observed by agarose gel electrophoresis in $1 \%$ agarose gel. $5 \mu$ l of each PCR product and the molecular mass marker ( $1 \mathrm{~kb}$ DNA ladder) were subjected to agarose gel electrophoresis and ethidium bromide staining. The PCR products were visualized by UV transilluminator and photographed.

\section{F. DNA Sequencing}

PCR product was purified according to the protocol in MEGAquick-spin ${ }^{\mathrm{TM}}$ PCR and Agarose Gel DNA Extraction system (iNtRON Biotechnology, Korea). The purified PCR product was submitted for DNA sequencing.

\section{G. Database Search of DNA Helicase}

DNA helicase gene sequence of $C$. albicans was available in National Center for Biotechnology Information (NCBI). A reference gene sequence of DNA helicase was selected from C. albicans SC5314. The reference DNA helicase gene sequence was named as C. albicans SC5314 potential DNA repair helicase (HPR5).

\section{H. Isolation of Genomic DNA from C. Albicans}

Cultured $C$. albicans cells were harvested at $\mathrm{OD}_{600}$ equal to 1.0. Genomic DNA of $C$. albicans was isolated using MasterPure $^{\mathrm{TM}}$ Yeast DNA Purification kit (Epicentre, USA). The genomic DNA of $C$. albicans was served as DNA template for amplification of DNA helicase gene.

\section{Identification of DNA Helicase from C. Albicans}

Standard PCR was carried out to obtain the DNA helicase gene of $C$. albicans. The optimized PCR reaction mixture contained of of $1 \mathrm{x}$ Phusion HF buffer with $1.5 \mathrm{mM} \mathrm{MgCl}$, $0.2 \mathrm{mM}$ dNTPs, $0.5 \mu \mathrm{M}$ of each primer, $100 \mathrm{ng}$ of genomic DNA, $0.02 \mathrm{U} / \mu 1$ Phusion DNA polymerase. The volume was made up to $50 \mu \mathrm{l}$ with sterile deionized water. The list of primers for standard PCR was shown in Table I. The restriction enzyme sites, HindIII and XhoI, were engineered into the forward and reverse primers, respectively. Standard PCR was performed under the following conditions, one cycle of $98^{\circ} \mathrm{C}$ for $30 \mathrm{~s}$ and 35 cycles of $98^{\circ} \mathrm{C}$ for $10 \mathrm{~s}, 61^{\circ} \mathrm{C}$ for $30 \mathrm{~s}, 72^{\circ} \mathrm{C}$ for $75 \mathrm{~s}$. Thermal cycles were terminated by polymerization at $72^{\circ} \mathrm{C}$ for $10 \mathrm{~min}$, and a final incubation at $4^{\circ} \mathrm{C}$. Then, visualization of PCR product by agarose gel electrophoresis in $0.7 \%$ agarose gel, and purification of PCR product was done as described above. The purified PCR product was submitted for DNA sequencing.

TABLE I: THE LIST OF SYNTHETIC OLIGONUCLEOTIDES

\begin{tabular}{ll}
\hline \hline $\begin{array}{l}\text { Name of the } \\
\text { oligonucleotide }\end{array}$ & DNA sequence (5' to 3') \\
\hline ITS1 & TCCGTAGGTGAACCTGCGG \\
ITS4 & TCCTCCGCTTATTGATATGC \\
F_HPR5 & GCGCAAGCTTATGATGCTGACGAGTAAT \\
R_HPR5 & GCGCCTCGAGTATCATCTTTTTAGGTTT \\
\hline \hline
\end{tabular}

\section{RESUlTS AND DisCUSSION}

\section{A. Isolation and Identification of Microorganism}

The most frequently used as isolation medium for Candida species is SDA [21]. This medium permits growth of Candida species, suppresses the growth of many species of oral bacteria because of its low $\mathrm{pH}$ [22]. In this study, the isolated microorganism developed as cream-white with soft consistency, round and convex surface with smooth margin colonies on SDA. ChromID Candida medium was used as a second differential medium for Candida species. The chromogenic culture medium produced blue colonies. Based on colony colour and appearance, the blue colonies indicated that this local isolated microorganism was Candida albicans.

ChromID Candida is a commercial chromogenic culture for the identification of Candida species. ChromID Candida is an agar medium utilizing the specific hydrolysis of a chromogenic substrate by the $\beta$-galactosaminidase of Candida albicans [23]. In fact, ChromID Candida has been proven beneficial for the presumptive identification of Candida albicans [24]. ChromID Candida was used as primary isolation with the combination of SDA.

\section{B. Microscopy Examination and Morphological Studies}

In general, morphological characteristics of isolated microorganism were examined using scanning electron microscope. The isolated microorganism was in ovoid or spherical-shaped with budding (Fig. 1). The germ tube test is a standard laboratory method for identifying C. albicans [25], [26]. The test involved the induction of hyphal outgrowths (germ tubes) from yeast cultured in fetal bovine serum for 3 hours at $37^{\circ} \mathrm{C}$. In this study, more than five germ tubes $(n>5)$ were formed, resulting in no false-positive in this test (Fig. 2). Therefore, the local isolated microorganism was indicated firmly as $C$. albicans. This test is very useful and economical for rapid identification of $C$. albicans since it gives results within 3-4 hours [23].

\section{Genotype Identification}

Various DNA-based methods have been developed to improve the identification of pathogenic fungi [27]-[29]. In this study, colony PCR was demonstrated using yeast cells directly as the DNA template without any DNA extraction and purification prior to PCR. Fig. 3 shows the result of 
agarose gel electrophoresis of direct PCR amplification and representative PCR products of the serial dilution of the isolated yeast cells with universal primer ITS1 and ITS4 respectively. The sensitivity of each dilution ranged from $10^{6}$ to $10^{7}$ cells, which indicated that the internal transcribed spacer (ITS) primers have the potential to amplify DNA directly from culture. The results showed that sensitivity of the colony PCR was $10^{6}$ cells for Candida sp. Due to this reason, colony PCR can be applicable to amplify DNA from different Candida sp. The ITS primers have been successfully amplified ITS1-5.8SrDNA-ITS2 region [30]-[32]. These primers had produced an amplicon of the appropriate size ranging from 530bp for C. albicans (Accession No. JN606270.1). No false-positive result was seen in this study. In fact, the preparation of DNA still requires a significant amount of time and cost. However, colony PCR is the most convenient and a rapid protocol for amplification of target DNA [32].

\section{Identifiction of DNA Helicase from C. Albicans}

The genome of $C$. albicans has been completely sequenced [33]. The C. albicans SC5314 potential DNA repair helicase (HPR5) sequence was obtained by searching in the National Center for Biotechnology Information (NCBI). Based on the sequence information, specifics primers for the gene were designed and used for PCR. Fig. 4 shows the result of agarose gel electrophoresis of potential DNA helicase with the size of amplicon was $2589 \mathrm{bp}$. Then, the purified PCR product was submitted for DNA sequencing. The BLAST result showed that the amplicon was $99 \%$ matched to C. albicans SC5314 potential DNA repair helicase (HPR5) sequence (Accession No. XM718088). However, there were some bases different from the reference DNA helicase gene sequence due to it was a local isolated C. albicans.

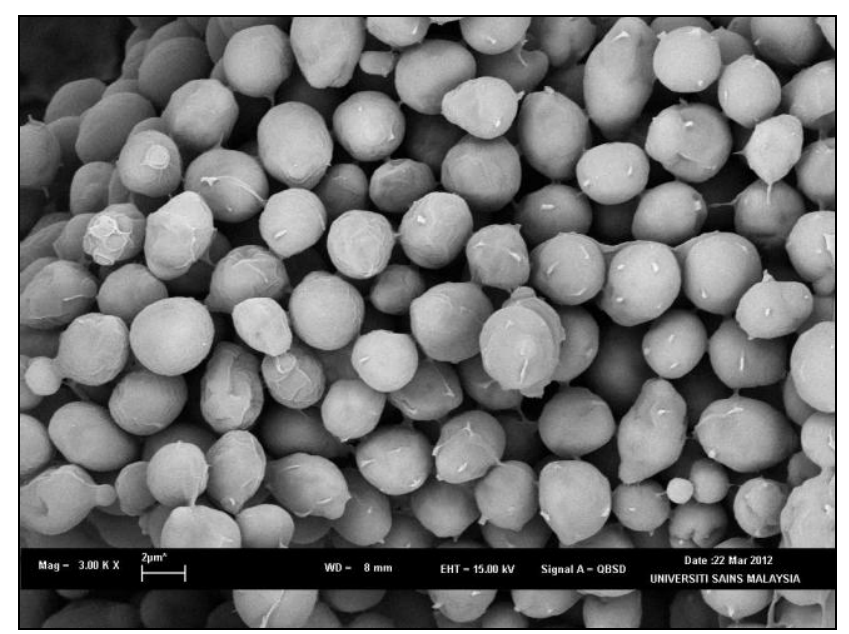

Fig. 1. SEM micrograph of isolated Candida sp. (3,000x).

\section{CONCLUSION}

Based on the results, the phenotype and genotype characteristics of local isolated microorganism have been proven as $C$. albicans in this study. The potential DNA helicase gene has also been successfully amplified from the local isolated C. albicans. Nevertheless, a further study of its enzymatic activity is essential in order to validate and verify its helicase unwinding properties in future.

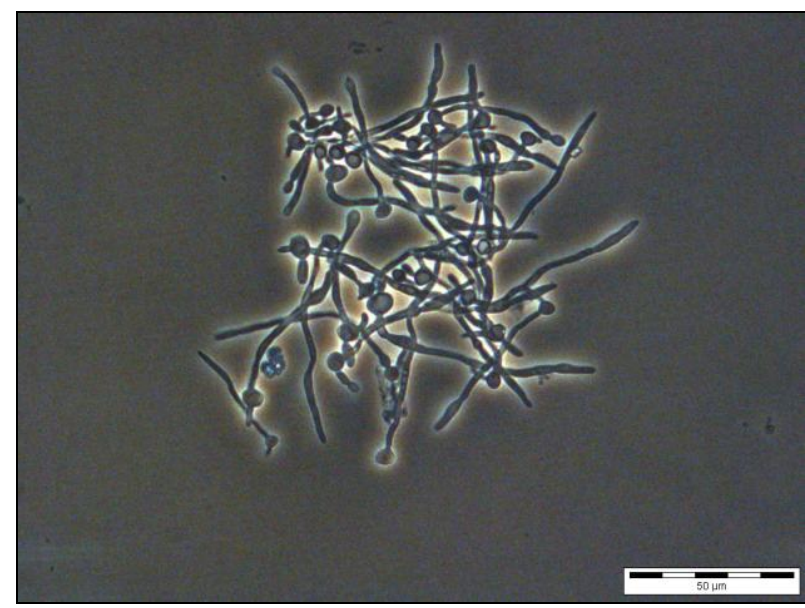

Fig. 2. Germ tube test of isolated Candida sp. (400x).

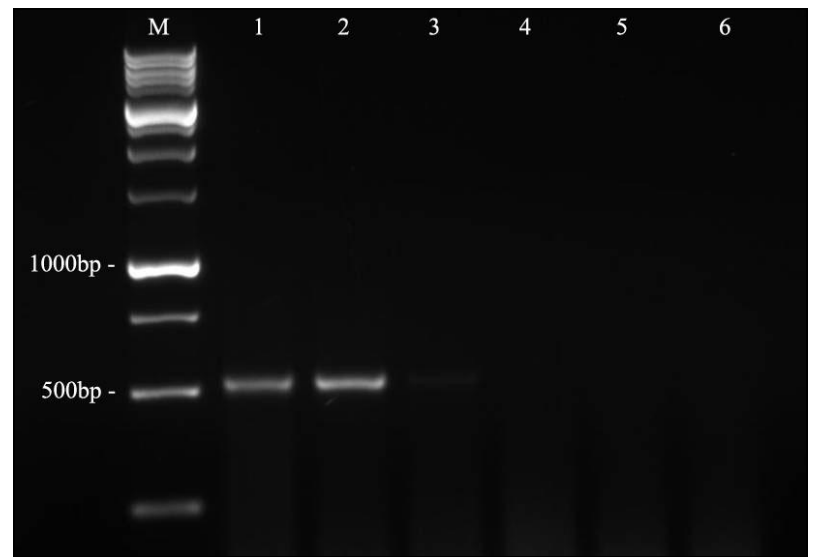

Fig. 3. Agarose gel electrophoresis of colony-PCR using universal primer ITS1 and ITS4 respectively, related to serially diluted of local isolated yeast. Lane M, 1kb DNA marker, Lane 1, direct colony-PCR, Lane 2-5, 107 to 104, Lane 6, negative control (without DNA template).

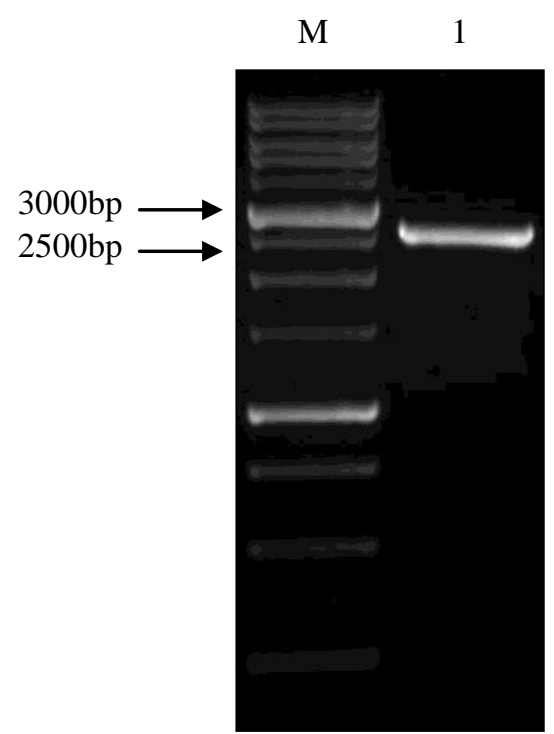

Fig. 4. Agarose gel electrophoresis of potential DNA helicase from local isolated C. albicans. Lane M, 1 kb DNA marker, Lane 1, PCR fragment with the size of $2589 \mathrm{bp}$.

\section{ACKNOWLEDGMENT}

I would like to express my gratitude to The Malaysian Ministry of Higher Education for providing the financial support. Special thanks to the staffs in School of Biological Sciences, USM and Institute for Research in Molecular Medicine (INFORMM), USM for their assistance in this project. 


\section{REFERENCES}

[1] P. Gill and A. Ghaemi, "Nucleic Acid Isothermal Amplification, Technologies - A Review," Nucleosides, Nucleotides, and Nucleic Acids, 2008, vol. 27, pp. 224-243.

[2] R. Naravaneni and K. Jamil, "Rapid detection of food-borne pathogens by using molecular techniques," Journal of medical microbiology, vol. 54, pp. 51-54, 2005.

[3] Y. Yamamoto, "PCR in diagnosis of infection, detection of bacteria in cerebrospinal fluids," Clinical and diagnostic laboratory immunology, 2002, vol. 9, pp. 508-514.

[4] Y. J. Jeong, K. Park, and D. E. Kim, "Isothermal DNA amplification in vitro, the helicase-dependent amplification system," Cellular andmolecular life sciences, 2009, vol. 66, pp. 3325-3336.

[5] W. H. A. Chow et al., "Application of isothermal helicase-dependent amplification with a disposable detection device in a simple sensitive stool test for toxigenic Clostridium difficile," The Journal of Molecular Diagnostics, JMD, vol. 10, pp. 452-458, 2008.

[6] A. Motré, R. Kong, and Y. Li, "Improving isothermal DNA amplification speed for the rapid detection of Mycobacterium tuberculosis," Journal of Microbiological Methods, vol. 84, pp. 343-345, 2011.

[7] M. Vincent, Y. Xu, and H. Kong, "Helicase-dependent isothermal DNA amplification," EMBO reports, 2004, vol. 5, pp. 795-800.

[8] J. Goldmeyer, H. Kong, and W. Tang, "Development of a novel one-tube isothermal reverse transcription thermophilic helicase-dependent amplification platform for rapid RNA detection,' The Journal of Molecular Diagnostics, vol. 9, pp. 639-644, 2007.

[9] M. Abdel-Monem and H. Hoffmann-Berling, "Enzymic Unwinding of DNA," European Journal of Biochemistry, vol. 65, pp. 431-440, 1976.

[10] M. C. Hall and S. W. Matson, "Helicase motifs, the engine that powers DNA unwinding," Molecular microbiology, 1999, vol. 34, pp. 867-877.

[11] T. M. Lohman and K. P. Bjornson, "Mechanisms of helicase-catalyzed DNA unwinding," Annual review of biochemistry, 1996, vol. 65, pp. 169-214.

[12] S. S. Patel and I. Donmez, "Mechanisms of helicases, Journal of Biological Chemistry, vol. 281, pp. 18265-18268, 2006.

[13] J. M. Caruthers and D. B. McKay, "Helicase structure and mechanism," Current opinion in structural biology, 2002, vol. 12, pp. 123-133.

[14] N. Tuteja and R. Tuteja, "Prokaryotic and eukaryotic DNA helicases," Journal of Biochemistry, vol. 271, pp. 1835-1848, 2004.

[15] J. Meurman, E. Siikala, M. Richardson, and R. Rautemaa, "Non-Candida albicans Candida yeasts of the oral cavity. Communicating current research and educational topics and trends in applied microbiology," Microbiology book series, Badajoz, Formatex, 2007, pp. 719-731.

[16] P. E. Sudbery, "The germ tubes of Candida albicans hyphae and pseudohyphae show different patterns of septin ring localization," Molecular microbiology, 2001, vol. 41, pp. 19-31.

[17] P. Sudbery, N. Gow, and J. Berman, "The distinct morphogenic states of Candida albicans," Trends in microbiology, 2004, vol. 12, pp. 317-324.

[18] M. Makut and E. Godiya, "A survey of cellulolytic mesophilic fungi in the soil environment of Keffi Metropolis, Nasarawa State, Nigeria," African Journal of Microbiology Research, vol. 4, pp. 2191-2195, 2010 .
[19] G. Molero et al., "Candida albicans, genetics, dimorphism and pathogenicity," International Microbiology, 1998, vol. 1, pp. 95-106.

[20] G. Ramage, K. V. Walle, B. L. Wickes, and J. L. Lopez-Ribot, "Characteristics of biofilm formation by Candida albicans," Revista iberoamericana de micolog ía, 2001, vol. 18, pp. 163-170.

[21] L. Samaranayake, T. MacFarlane, and M. Williamson, "Comparison of Sabouraud dextrose and Pagano-Levin agar media for detection and isolation of yeasts from oral samples," Journal of clinical microbiology, vol. 25, pp. 162-164, 1987.

[22] F. C. Odds, "Sabouraud ('s) agar," Medical Mycology, 1991, vol. 29, pp. 355-359.

[23] J. Hoppe and P. Frey, "Evaluation of six commercial tests and the germ-tube test for presumptive identification of Candida albicans," European Journal of Clinical Microbiology \& Infectious Diseases, vol. 18, pp. 188-191, 1999.

[24] P. Rousselle, A. M. Freydiere, P. J. Couillerot, H. De Montclos, and Y. Gille, "Rapid identification of Candida albicans by using albicans ID and fluoroplate agar plates," Journal of Clinical Microbiology, vol. 32, pp. 3034-3036, 1994

[25] J. L. Perry and G. R. Miller, "Umbelliferyl-labelled galactosaminide as an aid in identification of Candida albicans," Journal of Clinical Microbiology, vol. 25, pp. 2424-2425, 1988.

[26] C. L. Taschdjian, F. Reiss, and P. J. Kozinn, "Experimental vaginal candidiasis in mice, its implications for superficial candidiasis in humans," Journal of Investigative Dermatology, vol. 34, pp. 89-94, 1960.

[27] M. Gottfredsson, G. M. Cox, and J. R. Perfect, "Molecular methods for epidemiological and diagnostic studies of fungal infections," Pathology, 1998, vol. 30, pp. 405-418.

[28] E. Reis et al., "Molecular diagnosis and epidemiology of fungal infections," Medical mycology, official publication of the International Society for Human and Animal Mycology, 1998, vol. 36, pp. 249-257.

[29] D. W. Williams and M. Lewis, "Oral Microbiology, Isolation and identification of candida from the oral cavity," Oral diseases, 2000, vol. 6 , pp. 3-11.

[30] Y. Chen et al., "Identification of medically important yeasts using PCR-based detection of DNA sequence polymorphisms in the internal transcribed spacer 2 region of the rRNA genes," Journal of clinical microbiology, vol. 38, pp. 2302-2310, 2000.

[31] Z. Embong et al., "Specific detection of fungal pathogens by $18 \mathrm{~S}$ rRNA gene PCR in microbial keratitis," BMC ophthalmology, 2008, vol. 8, pp. 1-7.

[32] Mirhendi et al., "Colony PCR is a rapid and sensitive method for DNA amplification in yeasts," Iranian Journal of Public Health, 2007, vol. 36, pp. $40-44$.

[33] T. Jones et al., "The diploid genome sequence of Candida albicans," in Proc. the National Academy of Sciences of the United States of America 2004, vol. 101, pp. 7329-7334.

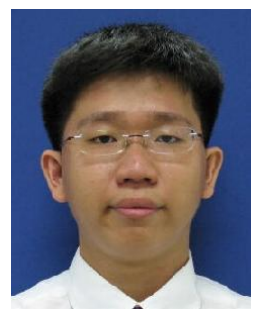

Haw Boon Ping was born in Penang, Malaysia on April 11, 1987. His B.Sc. is in Microbiology from Universiti Sains Malaysia (USM) in Penang, Malaysia. He is now doing his postgraduate study in M.Sc. in Molecular Medicine in USM, Penang, Malaysia. He started working as clinical research coordinator in a private sector from 2010 to 2012 His research interest is molecular medicine and molecular microbiology and its application. 